ISLAH: Journal of Islamic Literature and History

Vol. 1, No. 1, June 2020: p. 1-20. DOI: 10.18326/islah.v1i1.1-20

Website: https://e-journal.iainsalatiga.ac.id/index.php/islah

\title{
The Choice of Mood System in Functional Systemic Linguistics as Diplomacy Strategy (An Analysis of Classical Arabic Humor Conversation Discourse)
}

\author{
Tsaniananda Fidyatul Chafidzoh \\ Master Degrees of Arabic Language and Literature UIN Sunan Kalijaga Yogyakarta \\ ninda0330@gmail.com
}

\begin{abstract}
This study aims to examine the use of mood system in classical Arabic humorous conversations as a diplomatic strategy for Juha to Sulțan. Juha is a picture of commoners, and Sultan is a picture of a ruler. The humorous conversation is taken from the saga text entitled Juha wa as-Sultan by Ahmad Bahjat. This research is descriptive qualitative. The data were analyzed using method of distribution with direct elements (BUL) technique and utilizing the Halliday's Systemic Functional Linguistics (SFL) approach. The analysis showed that in a humorous conversation between Juha and Sulțan, Juha acted as an informant as well as a conversation topic holder. As an informant, Juha's speeh was $76.8 \%$ more dominant than Sulțan's in the indicative-declarative mood statement function. On the other hand, the Sultan indicative-interrogative mood system is dominant as $94.3 \%$. This shows Sultan's high social status, so he is free to use his authority to request information from interlocutors. In the use of the command speech function, Juha is more dominant by $14.2 \%$ with the choice of indicativedeclarative mood system. This shows that Juha, although socially lower than Sultan, does not prevent him from actively asking for goods or services from his interlocutors. Through this speech function, Juha controls the course of the conversation according to his needs.
\end{abstract}

Keywords: Arabic Classic Humor, Juḥa, Mood Systems, Systemic Functional Linguistics

\begin{abstract}
Abstrak
Penelitian ini bertujuan mengkaji penggunaan pilihan sistem mood dalam percakapan humor klasik Arab sebagai strategi diplomasi Juha kepada Sulțan. Juha adalah gambaran rakyat jelata dan Sulțan gambaran penguasa. Percakapan humor diambil dari teks hikayat berjudul Juḥa wa al-Sulțan karya Ahmad Bahjat. Penelitian ini bersifat deskriptif kualitatif. Data dianalisis menggunakan metode agih dengan teknik bagi unsur langsung (BUL) dan memanfaatkan pendekatan Linguistik Sistemik Fungsional (LSF) Halliday. Hasil analisis menunjukkan bahwa dalam percakapan humor antara Juḥa dan Sulțan, Juḥa berperan sebagai informan sekaligus pemegang topik percakapan. Sebagai informan, tuturan Juha lebih dominan 76,8\% dari Sultan pada fungsi tutur statement/pernyataan pilihan sistem mood indikatif-deklaratif. Sebaliknya, pada fungsi tutur question/pertanyaan pilihan sistem Mood indikatif-interogatif Sulțan lebih dominan 94,3\%. Hal ini menunjukkan status sosial Sulțan yang tinggi sehingga leluasa menggunakan kewenangannya meminta informasi dari lawan tutur. Pada penggunaan fungsi tutur command, Juha lebih dominan, 14,2\% dengan pilihan sisitem mood indikatif-deklaratif. Hal ini menunjukkan bahwa Juha walau secara status sosial lebih rendah dari Sulțan, tidak menghalanginya untuk lebih aktif meminta barang atau jasa dari lawan tuturnya. Melalui Fungsi tutur ini Juha mengendalikan jalannya percakapan sesuai kebutuhannya.

Kata kunci: Humor Klasik Arab, Juḥa, Sistem Mood, Linguistik Sistemik Fungsional
\end{abstract}




\section{INTRODUCTION}

One of the figures on classic Arabic humor stories is Juha. Juha is one of the Sufi mystical humorists of the 6th / 12th century AD who is a symbol of the character of humanity. He is known as Ramzun Fanniyyun. Regarding the identity or the owner of the nickname, Juha is actually still being suspected by the researchers. Some countries have a humorous figure named Juha. In Turkey the name is Nashrudin Khoja, and in Egypt the names are al-Faraziy and ar-Rumi. ${ }^{1}$ There is also Juha in the Arab region called Dajin bin Thabit or the nickname of Abu Ghushn, and there are many more in various countries who accept the title Juha. ${ }^{2}$ Nevertheless, Juḥa's anecdotes and humor such as Nawādir Juḥa al-Kubra are more reliant on Nashrudin Khoja. ${ }^{3}$

Several studies related to Juha were conducted by Mudawwam (2004) who examined Nashrudin Khoja's logic errors. The research found that there were 13 logical errors in the book Nawādir Juḥa al-Kubra. If these logical mistakes happen more intensively, it will make the story funnier. The logic error occurred was none other than because Juha was described as being stupid and foolish in character so that sometimes he could not distinguish between himself and his donkeys. ${ }^{4}$ Widyasari (2014), in his research entitled "al-Fakāhatu fi Nawādir Juha" found that Juha's story was full of advice, all of which were delivered in the form of humor. This shows the spirit of humanity possessed by Juha. If we examine Grice's maxim theory, the Juha's story initially corresponds to the four maxims. But, at the end of the story, a presupposition appears which makes the Juha story end up witty. ${ }^{5}$

Among the classic Arabic books that tell the story of Juha, there is a saga entitled Juha wa al-Sulțan, namely the humorous story of Juḥa which is included in the category of political criticism. ${ }^{6}$ This saga is one of the various sagas about Juha which contains a lot of dialogue. This saga was built from a collection of dialogues between Juha and Sulțan and several related royal parties. Juha's ignorance and ingenuity plus the rigidity of the royal protocol system made the dialogue in this saga interesting and had many variations. Variations in speech function and style of dialogue delivery in the dialogues of the Juha wa al-Sultan saga

\footnotetext{
${ }^{1}$ M. R. Najar, Juḥa al-Arabiy, (Kuwait: Ālamu al-Ma'rifah, 1978), pp. 33, 53

${ }^{2}$ A. M. Bisri, Dari Canda Nabi dan Sufi Sampai Kelucuan Kita, (Rembang: CV. Mata Air, 2016), p. 37

${ }^{3}$ A. Farraj, Akhbāru Juha, (Kairo: Maktabah Mișr, TT), p. 4. Lihat juga Najar, ibid, p 17

${ }^{4}$ S. Mudawwam, “Analisis Kesalahan Logika Pada Cerita Lucu Nasruddin Hoja dalam Buku Nawādir Juḥa", Graduating paper (Malang: Malang State University, 2004). 2014)

${ }^{5}$ M. Widyasari, "al- Fakāhatu fi Nawādir Juḥa", Graduating paper (Yogyakarta: UIN Sunan Kalijaga,

${ }^{6}$ A. Bahjat, Juḥa wa al-Sulțān, (Beirut: Dār al-Syurūq, TT), p. 4
} 
text, including the construction of the clause, are interesting to study from the lexicalgrammatical point of view using the Functional Systemic Linguistic theory (LSF). This is because the story of Juha wa al-Sultan was composed of active dialogues and his comments were humorous diplomatic.

Systemic Functional Linguistics introduced by M.A.K Halliday, a professor of linguistics at the University of Sydney Australia in $1985^{7}$ is an approach that emphasizes systemic and functional language. Systemic refers to the language system formed through elements of expression, form and meaning. The functional refers to the understanding that language has a metafunction. Language metaphy consists of ideational (experimental and logical), interpersonal, and textual functions. ${ }^{8}$

In line with the SFL concept above, Bardi (2008), in the results of his dissertation research entitled "A Systemic Functional Description of the Grammar of Arabic", states that Arabic has its own complex grammar and character which is far more advanced when juxtaposed with the other languages. ${ }^{9}$ The combination of Arabic grammatical analysis from its predecessor linguists conducted by al Jurjani shows that Arabic grammar is close enough to be elaborated with systemic functional grammatical theory

According to Bardi, the ideational function is to construct and realize participants' experiences. Interpersonal function, related to the interaction of several participants said. The realization of this function is in the mood system, ${ }^{10}$ while the textual function is a summary or realization of both functions. The ideational function can be seen from the choice of the use of language or words along with the context and situation around them. Through this theory, it can be explained about the meaning system of cultural values of the community which is reflected in the use of language by the community. ${ }^{11}$ The choice of language use and all conditions of the situation and the supporting social context is a social semiotic. SFL places the text as a social interaction. ${ }^{12}$

\footnotetext{
${ }^{7}$ L. D Gerot, Making Sense of Functional Grammar (Sydney: Antipodean Educational Enterprise, 1996), $\mathrm{p}$

${ }^{8}$ M. Halliday, An Introduction of Functional Grammar, (London: Arnold, 2014), p 30-31

${ }^{9}$ M. A. Bardi, "A Systemic Functional Description of The Grammar of Arabic", Tesis, (Sydney: Macquarie University, 2008) pp 2-5

${ }^{10}$ Ibid, p 49

${ }^{11}$ R. Santoso, Semiotika Sosial: Pandangan terhadap Bahasa, (Surabaya: Pustaka Eureka, 2003), p 14

${ }^{12}$ Djatmika, Perilaku Bahasa Indonesia di Salam Teks Kontrak dari Kaca Mata Linguistik Fungsional (Surakarta: UNS Press), p 10
} 


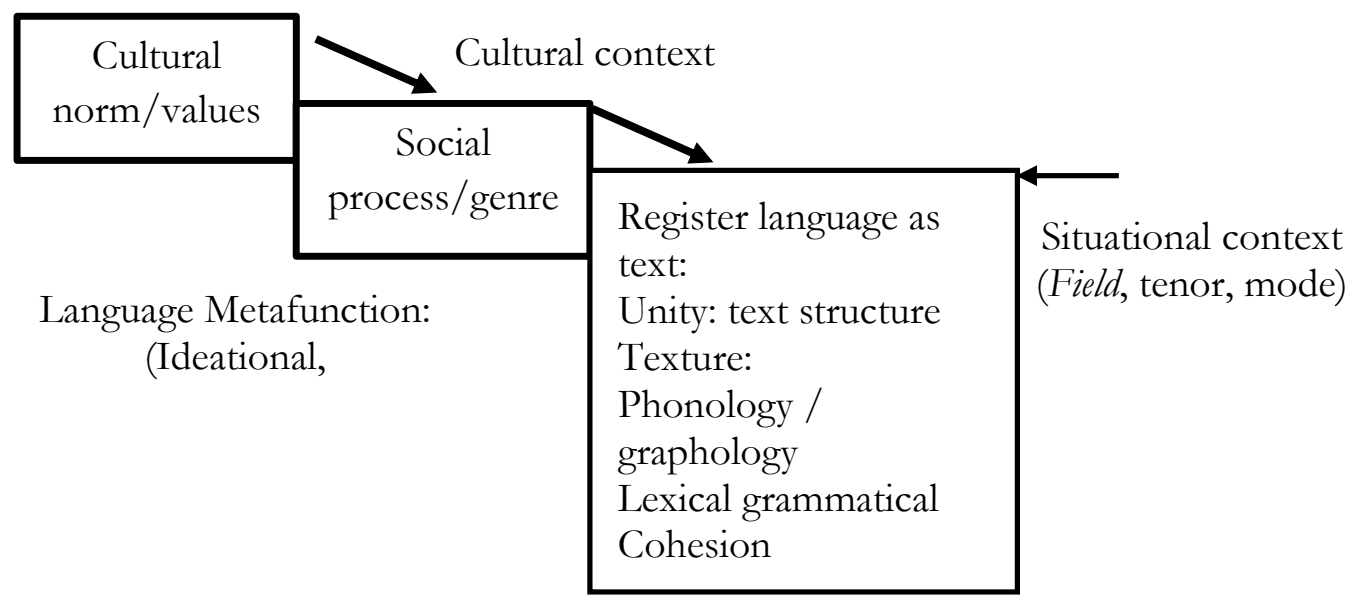

Diagram 1: social semiotic in LSF

Bardi further explained that mood in interpersonal function is a form of realization of interaction between participants (exchange). Through the choice of the mood system, the speech participant can be creative in expressing his intended intentions and meanings. The purpose and meaning desired by the speech participant is then referred to as the speech function. The combination of the types of speakers' wishes and the things that are desired to be exchanged gives rise to four speech functions, namely: (1) giving information: giving rise to the speech function of statements, usually in the form of indicative-declarative clauses; (2) providing goods or services: giving rise to the function of offer speech, indicative-declarative, indicative-interrogative, or imperative clause forms; (3) asking for information: giving rise to the question function, indicative-interrogative clause form; and (4) asking for goods or services: bringing up the command speech function, most of which are in the form of imperative clauses. The four speech functions mentioned in the clause are realized by the mood system, which is an interpersonal fundamental system in any language. ${ }^{13}$

There are two kinds of mood systems in the Arabic clause, indicative and imperative. In the indicative mood system there are three variants, namely declarative (statement), exlamative (surprise or amazement), and interrogative (question). As for the imperative mood system, there are two variants of forms, namely inclusive and exclusive. The inclusive imperative is a form of command composed of $l i+$ al mudari 'al-majzum particles, while the exclusive imperative is a form of direct order.

This paper aims to obtain an objective description of the realization of the lexical grammatical in the mood system in the dialogue clauses of Juḥa wa al-Sulțan. Among these

\footnotetext{
${ }^{13}$ Bardi, ibid, pp. 206-240
} 
are to (1) describe the realization of the mood system in each choice of speech function in the dialogue saga Juḥa wa al-Sulțan, and (2) describe the diplomacy strategy carried out by Juha and Sultan based on the choice of the existing mood system.

\section{METHODOLOGY}

This research is qualitative descriptive. Qualitative research takes research data from various phenomena and symptoms that arise in everyday life. The use of descriptive methods is to describe the phenomena and symptoms from the data studied. Through this method, the research object is described and interpreted as is but systematically based on its characteristics. The data in descriptive qualitative research are treated in three stages, namely data collection, data analysis, and presentation of data analysis results. ${ }^{14}$

The data collection stage uses the method of listening with tapping techniques, free listening and speaking, and taking note. ${ }^{15}$ At this stage the researcher is observing the text of the story of Juḥa wa as-Sulțan by Ahmad Bahjat. The data collected are conversational clauses between Juha and Sulțan, leaving clauses that explain the setting of the place and the like. For data analysis, the method used is the technique of direct elements (BUL) and systemic functional linguistic (SFL) analysis approach. At this stage, the data of the clauses collected as the object of research are broken up with the BUL technique by referring to the SFL theory used. These clauses are divided based on the type of speech function and mood system, and the mood structure of its constituents. After the clause data is treated using the BUL technique, the researcher analyzes the course of the conversation by considering the type of speech function and mood system choices in the research object. The last stage of the study is the presentation of the results of the analysis. The results of the analysis in this study are presented in the form of a description. ${ }^{16}$

\footnotetext{
${ }^{14}$ Sudaryanto, Metode Linguistik: Ke Arah Memahami Metode Linguistik, (Yogyakarta: GMU Press, 1986), p 57

${ }^{15}$ Mahsun, Metode Penelitian Bahasa, Tahapan Strategi, Metode dan Tekniknya, (Jakarta: Rajawali Press, 2007) pp 92-93

${ }^{16}$ Sudaryanto, Metode dan Aneka Teknik Analisis Bahasa: Pengantar Penelitian Wahana Kebudayaan Secara Linguistik, (Yogyakarta: Duta Wacana University Press, 2005), p 123
} 


\section{DISCUSSION}

\section{Realization of the Speech Function in the Humor Dialogue Text of Juha wa al-Sulțn}

In the saga text, there are clauses of conversation between Juha and Sulțan. The overall clauses studied, totaling 165 clauses. From the number of clauses, there are four types of speech functions used in conversation, namely statements, questions, commands, and offers. Of the four types of speech functions available, it was found that the most dominant type of speech used in interaction was the statement speech function, which was 112 clauses or $67.89 \%$ of the total conversation. This shows that the dialogue in the saga of Juha wa alSultan was built by the interaction of exchanging information.

In the second position there is a question function which has function to request information from the speech partner, namely 35 clauses or $21.21 \%$ of the total conversation. Following underneath is the command (request) speech function of 14 clauses or $8.48 \%$ of the entire conversation. This speech function is used by the speaker to request goods or services from the speech partner. In the final position, the speech function that is very small in frequency is the offer, which is only used in 4 clauses or $2.42 \%$ of the entire conversation. The function of the offer speech is used to convey the intention to provide goods or services to the speech partner. So, in a diplomatic conversation this speech function is rarely used. This is because the participant of the speech carries the aims and objectives that are being fought for through dialogue with the speech partner.

\section{Mood System Options in the Statement Speech Function}

Statements are speech functions that have the function of "giving information" and are generally in the form of declarative indicative clauses. ${ }^{17}$ This is consistent with the findings of the interactions made by Juḥa and Sulțan in the saga of Juha wa al-Sulțan. By choosing the speech function of the statement, the speaker wishes to provide information to the interlocutor. Following is the use of the mood system in the speech function statement by each speech participant.

\footnotetext{
${ }^{17}$ Bardi, ibid, p 206
} 


\begin{tabular}{|c|c|c|c|c|}
\hline \multirow{3}{*}{ Speaker } & \multirow{2}{*}{\multicolumn{2}{|c|}{$\begin{array}{l}\text { Statement } \\
\text { function }\end{array}$}} & \multicolumn{2}{|c|}{ Mood system } \\
\hline & & & \multirow{2}{*}{$\begin{array}{c}\text { Ind-Declarative } \\
\text { Frequency }\end{array}$} & \multirow{2}{*}{$\begin{array}{c}\text { Ind- } \\
\text { interrogative } \\
\text { Frequency }\end{array}$} \\
\hline & $\mathbf{F}$ & $\%$ & & \\
\hline Juḥa & 86 & 76.8 & 85 & 1 \\
\hline Sulțan & 26 & 23.2 & 24 & 2 \\
\hline Total & 112 & $100 \%$ & 109 & 3 \\
\hline
\end{tabular}

Table 1: Mood System in the Statement Speech Function by Juha and Sulțan

The table above shows 112 clauses spoken in statement speech functions. Juha is the party that uses statement speech functions more often than Sulțan. The difference in the use of speech function statements between Juha and Sulțan is very sharp, namely 86 clauses versus 26 clauses. Both speakers, both Juḥa and Sulțan use the indicative-declarative and indicativeinterrogative mood system with a minimum frequency of occurrence in the indicativeinterrogative mood system.

In accordance with Bardi's statement, the function of speech form statement is generally in the form of indicative-declarative clause. This does not mean that statement speech functions are only indicative-declarative clauses. ${ }^{18}$ It is possible that the speech function statement is realized with a mood system other than that. As found in the dialogues in the story of Juḥa wa al-Sulțan, three indicative-interrogative clauses contribute to the choice of statement function.

The dominance of the speech function use of the statement by Juha explains that Juha is the party who is the source of information as well as the holder of conversation themes in the context of the saga text Juha wa al-Sulțan. In addition, the table above also shows that Juha, as a social class that is lower than Sulțan, is only able to be a party that responds to requests for information. Information for the upper social class is not something that can be obtained, so it appears from the table that Sultan has a small percentage in the function of this statement.

Realization of the use of the indicative-declarative mood system by Juha is huge because Juha as the informant and holder of the conversation topic, he likes to extend his

\footnotetext{
${ }^{18}$ Ibid, p 18
} 
speech and reproduce information for Sulțan, when Sulțan asks something light or simple. As in Juha's answer:

"Anā asytagil 'àliman. Anā kullu man baqiya minal-'ulamā' fil-mamlakah. Wa lākinnan̄i 'àlimun fil-ḥamqi. Wa lastu a'rifu ayya syai in urīd. Lam akad arā wajha jalālatas-sulțān. Hattā ugmiya 'alā 'aqlī. Tażakkartu, Anta allażī yurīdunì lā anā”

"I work as a cleric. I am the last scholar of all the scholars in this craft. However, I am a cleric in terms of ignorance and I do not know what I want. I could barely see His Majesty's great face until I was dazed. Now I have recalled, that it really is not me but the Glorious One who wants me "

The Juha's statement was the answer when responding to the Sulțan question "māżā ta'mal wa ayyu syai in turīd?" which means "what are you doing and what do you want?". Juha gives answers that they are not as short and simple as they should be. Juha chose to introduce himself silly as a foolish cleric who did not even know his wishes. The purpose of his arrival was returned by Juḥa to Sulțan by saying that it was Sulțan who really wanted his arrival. For a Sulțan, the statement "Anta allażī yurīdunī lā anā." certainly is a degrading form because the Sulțan's social strata are higher than Juha's. What exists, should be, when people come to Sultan is because they ask for help or report on a situation not the other way around as Juḥa said. Despite the statement “Anta allażī yurīdunī lā anā.” can be considered a form of degrading Sulțan, this clause is also a clause that can make the Sulasaranan curious about Juha. This is what Juha is doing with Sulțan. He tried to draw the flow of dialogue in the direction Juḥa wanted.

Instead, Juha chose to shorten and shorten Information for Sulțan when Sulțan asked substantive questions. Consider the following Juha's answers:

\section{"Qalbī yuḥdisinnì bi annaka qātilī”}

"My heart says that His Majesty will kill me"

The statement in the form of the indicative-declarative clause was said by Juha when the Sulțan asked "Limāżā taẓunnu annanī sa`aqtulaka?" which means "why do you think that I will kill you later?" Through this question, using the question word "why", Sulțan is clearly 
in need of information from Juha about the reason he suspected that Sulțan would kill him. Juha should respond to this question with an answer beginning with "li annanī..." which means "because of me ...". Then Juha strengthens it with argumentative logical reasons based on facts. For example, as based on rumors circulating about the behavior of the Sultan towards the former royal clerics or the attitude of the Sulțan, it was considered firm in giving punishment or other reasons that could strengthen his allegations towards the Sultan.

But apparently Juḥa's answer was far from argumentative and factual based. Juḥa gives a reverse answer, is not logical and uses mere instinct, namely "Qalbī yuḥisiunī bi`annaka qātilı̄” which means "my heart says that the noble will kill me". The answer chosen by Juha can be categorized as an answer that benefits Juḥa and does not harm the Sulțan. This answer is categorized as beneficial for Juha because with his answer which is subjective, illogical, and relying on that instinct he is still awake in his authority, awake from the wrath of the Sulțan, and gives the impression of his stupidity. Then this answer is categorized as not giving harm to the Sulțan because in the clause "Qalbī yuḥdišunī bi annaka qātilì̄" " the Sulțan is not used as a subject or core reason Juha suspected that the Sultan would kill him. This answer at the same time also does not provide a gap and cause for Sultan to show his wrath.

As for Sultan, he uses the statement speech function to provide information in the form of his response and evaluation of Juha.

"Laqad najaha Juha fī imtiḥānihit-tahrīrī. Wa aśbata annahu syujā'un. Kāna yaḍhaku fi wajhis-sihāmi. Innanī āmura an yu 'țā Juḥa jubatan wa qafțānan wa "imàmatan badala mā kharaqtuhu al-sihāma"

"You succeeded in your mental test Juha. That strengthens your strength. You are able to laugh at an arrow right in front of you. Really I have told the palace maid to prepare a change of clothes that was hit by an arrow"

The indicative-interrogative clause type found only three clauses, one Juha speech clause and the other two were Sulțan speeches.

"Alam yantahis-sulțān min imtiḥānihi ba 'du?"

"Hasn't His Majesty finished his test?" 
Juha uses the indicative-interrogative type of speech clause when he tries to inform Sulțan that Sulțan has given many questions to Juḥa. The questions that Sulțan asked, according to Juḥa, were Sulțan's tests on him, because the questions posed by Sulțan were intended to extract information from Juḥa. The statement said by Juḥa was to refute Sulțan's speech that questioned Ju waktua's time to be tested.

Sulțan uses the indicative-interrogative type of speech clause when he tries to refute Juḥa's statement.

"Ataẓunnu al-imtihānu sahlan bi hażihi al-darajah?”

"Do you think the test is this easy to achieve the desired degree?"

By following the Juḥa pattern using the indicative-interrogative mood system, Sulțan emphasized an information that was misunderstood by Juha that to achieve the degree of the ulema of the kingdom the test was not as easy as the questions that were asked at the beginning. The use of the same pattern with the intention of emphasizing the opposite of speech is done by Sulțan to Juḥa as a counter statement to the pressure that Juha has put first through an indicative-interrogative pattern. However, even with the same pattern and with the same intentions of suppressing opponents, the Sulțan statement has a higher pressure than Juha because of the influence of social status and its later appearance than the Juha statement.

\section{Mood System Options in the Question Speech Function}

Question is a speech function that functions as "asking for information" and in the form of indicative-interrogative clauses. The question speech function has two types, namely polar question and elemental question. ${ }^{19}$ The following is the use of the question speech function and its type:

\footnotetext{
${ }^{19}$ Ibid.hal 210
} 


\begin{tabular}{|c|c|c|c|c|}
\hline \multirow{3}{*}{ Speaker } & \multirow{2}{*}{\multicolumn{2}{|c|}{$\begin{array}{l}\text { Question } \\
\text { Speech } \\
\text { Function }\end{array}$}} & \multicolumn{2}{|c|}{ Question Types } \\
\hline & & & Polar question & Elemental question \\
\hline & $\mathbf{F}$ & $\%$ & Frequency & Frequency \\
\hline Juḥa & 2 & 5.7 & - & 2 \\
\hline Sulțan & 33 & 94.3 & 6 & 27 \\
\hline Total & 35 & $100 \%$ & 6 & 29 \\
\hline
\end{tabular}

Table 2: The Mood System in the Question Speech Function by Juha and Sulțan

The table above shows that there are 35 clauses spoken using the question speech function. Sultan is the party that uses the question function more often than Juha. The difference in the use of the question speech function between Sulțan and Juha is very sharp, which is 33 clauses versus 2 clauses. This use can be interpreted that Sultan is showing its position as a party that has a higher social status than Juḥa. The authority of the Sultan as the ruler of the kingdom causes the Sulțan to have more power and flexibility in satisfying his desire to dig up information by interrogating his speech partner.

In accordance with Bardi's statement ${ }^{20}$ that the function of questioning is sometimes the type of polar question (yes-no question) can also be of the elemental question type. In the type of polar question, only Sulțan has the need to ask for certainty about information from Juha. Sulțan uses this type seven times whereas Juha, does not use this type at all. Here is an example question with the type of polar question:

\section{"Hal ta 'rifu lugat al-ḥayawāni?"}

"Do you understand animal language?"

The Sultan question above aims to find out the Juha's abilities and talents because of seeing Juha's previous behavior which can calm his donkey by whispering something in the ear of a donkey. From that question it is enough for Juha to give the answer "na'am" which means "yes" rightly that he knows the language of animals or "la" which means "no" right that Juha knows the language of animals.

\footnotetext{
${ }^{20}$ Ibid.hal 210
} 
The type of elemental question in a large number of clauses is used by Sultan in conversation. There are 27 elemental question clauses which are the choice for Sultan to submit questions to Juḥa. Whereas Juha does not use mood system choices other than the elemental question type to give questions to Sulțan, the number of Juha clauses only appears 2 times.

The frequent use of elemental question types by Sultan is not without intention and purpose. As explained in the theoretical basis, the type of elemental question is the type of question that does not require an answer "yes / no" or yes-no question. This indicativeinterrogative mood system type elemental question requires speech partners who are asked to provide detailed and clear answers to the questions asked.

From a total of 27 question clauses spoken by Sulțan, there are three models of Sulțan objectives in using this type of elemental question, namely (1) Sulțan uses this type of elemental question to merely make small talk to Juha, (2) because of Sulțan curiosity to Juha or something other things that bother him and (3) the purpose of using elemental questions is to test Juha. The following are examples of the types of elemental questions spoken by Sultan to Juḥ:

\section{“Aina taẓunnu anna maqāmī sayakūnu fī al-akhirati?"}

"In your opinion, where will I return later in the afterlife?"

As for Juha, he asked using the type of elemental question is to ascertain about a matter to the East Sulawesi which through that certainty, Juha gained more information to benefit himself and see the possibilities that arise about him in the future. Consider the following clause:

\section{"Kam șinfan zāra al-gurfata qabla i'dāmihi?"}

"How many types of guests have visited this room before he was executed?"

Juha's question in the above clause seems to be a mere courtesy, but in truth he is asking and assuring the Sultan Timurlenk about the fate of the guests of the royal clerics and others before him. Question "How many types of guests have visited this room before it was executed?" this confirms that Juha, as part of the royal cleric as when introducing himself at the outset, needs to know and measure how much the test will await him in the future. The 
answer given by Sultan from that question affirms that all of them have visited the room without giving information or circumvention about the sentence of execution. Sultan said “Zāraha al-jamī‘u yā Juḥa”which means "all of them have visited him, Juha". This became the emphasis and awareness of Juha that no one of the royal clerics had survived the Sultan punishment. Juha increasingly understands that the test that awaits him in the future must be hard and there is not necessarily an opportunity to survive Timurlenk's death sentence.

\section{Mood System Options in the Command Speech Function}

Command is a speech function that has the function of "asking for goods or services" and can be in the form of imperative and indicative clauses. ${ }^{21}$ This is consistent with the findings of the interactions made by Juḥa and Sulțan in the saga of Juḥa wa al-Sulțan. Following is the use of the mood system in the command speech function by each speech participant:

\begin{tabular}{|c|c|c|c|c|c|}
\hline \multirow{3}{*}{ Speaker } & \multirow{2}{*}{\multicolumn{2}{|c|}{$\begin{array}{l}\text { Command } \\
\text { Speech } \\
\text { Function }\end{array}$}} & \multicolumn{3}{|c|}{ Mood System } \\
\hline & & & \multirow{2}{*}{$\begin{array}{c}\text { Ind- } \\
\text { Declarative } \\
\text { Frequency }\end{array}$} & \multirow{2}{*}{$\begin{array}{c}\text { Ind- } \\
\text { Interrogative } \\
\text { Frequency }\end{array}$} & \multirow{2}{*}{$\begin{array}{l}\text { Imperative } \\
\text { Frequency }\end{array}$} \\
\hline & $\mathbf{F}$ & $\%$ & & & \\
\hline Juḥa & 8 & 57,1 & 4 & 1 & 3 \\
\hline Sulțan & 6 & 42.9 & 1 & 1 & 4 \\
\hline Total & 14 & $100 \%$ & 5 & 2 & 7 \\
\hline
\end{tabular}

Table 3: Mood System in Command Speech Function by Juha and Sulțan

The table above shows that there are 14 clauses from all data that use the command speech function. There are three variations in the choice of mood system used, namely indicative-declarative, indicative-interrogative, and imperative. The frequency of the use of this speech function between Juha and Sultan is quite balanced. Although the number of uses is not as much as the statement or question speech functions, all variations of the command's speech function are used by the speech participants. This usage explains every participant of the speech, both Juḥa and Sulțan have a need to use the command's speech function. The existence of the use of this command speech function needs to exist in diplomatic conversations in order to control the course of communication so that it returns to the destination or purpose desired by the speaker.

\footnotetext{
${ }^{21}$ ibid, hal 226
} 
The following are examples of Juha's utterances that use the indicative-declarative mood system command speech function:

"Taqūlu al-ḥamīru, Inna al-Sulțan lau waḍa 'a șaifahu fi gamiḍihi. Lakāna hāżā ad'à ilā al-`amni wa al-`amāni”

"The donkeys said, If Sulțan put his sword in the sheath. This will invite security and peace."

The command speech in the form of the indicative-declarative mood system above was spoken by Juha when he was asked by Sulțan about what he whispered to the donkey. Juha also related that the donkeys said "Inna al-Sulțan lau waḍa'a șaifahu fi gamiḍihi. Lakāna hāżā ad'ā ilā al-`amni wa al-`amāni.” which means "if Sulțan puts his sword in a scabbard, it will invite security and peace".

It is illustrated in the saga that Sulțan was wielding a sword since his anger at his rest was disturbed by a deafening sound. Then it is not possible for Juha who wants the sword to be sheathed, conveyed it to Sulțan in an imperative form. These Juha donkeys' neighs are what later the Juha's media to convey his intentions become.

The three clauses above only contain one command speech function. This is because if each of the above clauses is categorized as the speech function, the intention of the speaker or Juha is not conveyed. The purpose of the above speech is for Sultan to sheath his unsheathed sword. The purpose of this speech function is to govern. However, due to consideration of different levels of social status and the possible risks received by Juha if the intentions of his wishes are conveyed imperatively, Juha chooses to use an indicative-declarative mood system without reducing the intention to be conveyed to Sulțan.

The Juha utterance which uses the indicative-interrogative mood system has only one clause, as follows:

\section{“Alā tas`alunī limāżā awwalan?”}

"Didn't you first ask me why"?

In the above clause Juḥa asks Sulțan in the form of an indicative-interrogative mood system "don't you first ask" why? ". This Juḥa question is clearly not for information but rather he is asking Sulțan to ask "why" first. For Juha maintaining the flow of conversation is 
important so that the intention he wants to reach Sulțan does not shift or change. For Sulțan the Juha question is a good suggestion so that his curiosity is answered so that there is no harm in Juḥa's suggestion being made.

The Sulțan utterance that uses the indicative-interrogative mood system is only one clause, as follows:

"Fa māżā kāna yajibu an akhtāra min hāżihi al-alqāb?"

"Then what kind of nickname should I choose from the many titles?"

The above clause in the form of the indicative-interrogative mood system is a Sultan speech when asking Juha's opinion regarding the proper nickname for Sultan. In this question Sulțan uses the word "yajibu an akhtāra" which means "I must choose". This explains that Sultan did not only ask Juha's opinion but also ordered Juha to give advice and contribute suggestions for the nickname for Sul untukan to be propped up to him.

Examples of Sultan's utterances that use the command speech function with imperative mood system choices are as follows:

"Inșarif al-ān ilā gurfati al-ḍuȳff"

"Now go to the guest room"

In the clause above Sulțan asks Juha for something, which is to go to the guest room. This order eventually became a necessity for Juha to do without rejection or refutation.

As for the clauses when Juha uses the command speech function in imperative form, there are three clauses. The first two utterances he addressed to his donkeys neighing in the middle of his dialogue with the Sulțan and once he said it to the Sulțan, which is like the following example:

\section{“Da 'ka min hāżihi al-alqāb”.}

"Forget those titles, Your Honor." 
The above clause is Juha's answer to the Sulțan question in the clause "Fa māżā kāna yajibu an akhtāra min hāżihi al-alqāb?". The command speech function spoken by Sulțan in the clause gets an answer also in the form of a command from Juha. Even the command spoken by Juha uses an imperative mood system in which the level of demand is higher than the command spoken by Sulțan, which is indicative-interrogative. Through this clause, Juha appears to be showing a side of his courage in rebelling against the Sulțan's will.

\section{Mood System Options in the Offer Speech Function}

Offer is a speech function that has the function of "giving goods or services" and can be in the form of imperative and indicative clauses. ${ }^{22}$ Following is the use of the mood system in the speech offering function by each speech participant:

\begin{tabular}{|c|c|c|c|c|}
\hline \multirow{3}{*}{ Speaker } & \multirow{2}{*}{\multicolumn{2}{|c|}{$\begin{array}{c}\text { Offer Speech } \\
\text { Function }\end{array}$}} & \multicolumn{2}{|c|}{ Mood System } \\
\hline & & & Ind-Declarative & Ind-interrogative \\
\hline & $\mathbf{F}$ & $\%$ & Frequency & Frequency \\
\hline Juḥa & 3 & 75 & 2 & 1 \\
\hline Sulțan & 1 & 25 & - & 1 \\
\hline Total & 4 & $100 \%$ & 2 & 2 \\
\hline
\end{tabular}

Table 4: The Mood System in the Offer Speech Function by Juha and Sulțan

The table above shows that the offer speech function is only used in the form of indicative-declarative and indicative-interrogative clauses. None of the speech participants used the offer speech function in the form of an imperative mood system. Even in its use, only one function of the offer speech is spoken by Sulțan and the rest is spoken by Juha. Here is an example of the offer speech function:

“Wa fĩ muqābili żalika sa`ațlu al-Sulțana 'alā syai’in muḍisyin. Sa`aqūmu bita 'līmi wāhidin min hamìiri al-khamsati kaifa yaqra"”

"In return, I will give an amazing gift to His Majesty. I will teach one of my five donkeys how to read. "

${ }^{22}$ Ibid. hal. 240 
The two clauses above are Juha's speeches when they end their conversation with Sulțan. The first word chosen by Juḥa in this clause is "Wa fī muqābili żalika" which means "in return". It is told in the saga that Juha succeeded in impressing Sulțan with him and there was no decision on his death sentence. In fact, Sulțan made him a friend living in the palace. In return for the virtue of the Sulțan Juha said the offer speech function by choosing a form of indicative-declarative mood system to give gifts to Sultan. The choice of mood system was chosen by Juḥa because the context was that Juḥa was giving gifts to Sulțan. Juḥa is not offering a gift to Sulțan, so her speech is not in the form of an indicative-interrogative mood system. Juha is also not asking Sultan to accept gifts from him so that it is not in the form of an imperative mood system. But in the clause, Juha is giving a gift to Sulțan. Then the form used is the indicative-declarative mood system. This is nothing but a reward for the virtue of the Sulțan who kept Juha alive even alongside the Sulampinganan.

\section{Juha and Sulțan Diplomacy Strategies based on Mood System Options}

As described above, that in the statement speech function, Juha is dominant with the choice of indicative-declarative mood system. The use of this mood system is adjusted to Juha with his social status. However, this does not prevent Juha from remaining the party holding the topic of conversation, namely by making modifications to the answers in the form of statements, when to be extended and when to shorten the information to provoke more curiosity from the Sulțan. In addition, Juha shows its ability to control the topic of conversation as seen from the use of the command speech function which maximizes the choice of indicative-declarative, indicative-interrogative, and imperative mood systems. In this speech function, Juha excels $14.2 \%$ or 2 clauses. Even though there are only two clauses, this shows that speakers who are socially inferior to their interlocutors are able to create space to govern or demand goods or services from a higher class in more quantities than they deserve.

Juha's agility in choosing the mood system in this command speech function needs to be examined and studied in conducting diplomacy. The purpose of the command cannot only be conveyed in the form of an imperative clause. The choice of indicative-declarative and indicative-interrogative mood systems also needs to be considered in the use of a diplomatic conversation. When Sulțan launches the purpose of the command to Juha by using the choice of the indicative-interrogative mood system, Junyaa responds with the intention of the 
command also in the choice of the imperative mood system. This shows Juha's courage and a severe blow to Sulțan.

As for Sulțan, because he is influenced by his higher social status which is very attached to him, he uses his authority to dig up information of the interlocutor. So it appears in the description above, that Sultan uses more the function of speech questions by choosing the mood elemental question system during the course of the conversation. This mood system selection puts Sultan in a position that can freely put pressure on Juha to always and provide more information not just "yes" or "no" answers as if the type of question chosen was the polar question type.

\section{CONCLUSION}

The classic Arabic humor genre text Juha wa al- Sultan contains the intention of political criticism from the people towards its ruler. The criticisms were packaged in the form of diplomatic dialogue between Juha and Sulțan. The dialogues that are built are very varied and both speakers maximize almost all mood system choices in each speech function. Skill in choosing a mood system when throwing questions and giving answers is important to ensure speakers reach their desired goals. Sulțan wants to finish off all religious leaders only because of his failure to answer questions that Sulțan has given. Whereas Juha, after seeing that many victims had been killed in vain, he tried to risk his life by responding to Sultan's questions.

The end of the dialogue shows that Juha survived the death threat that Sultan wanted to give him as well as to Juha's predecessor. There is Juha's expertise in winning diplomacy with Sultan, including by maximizing the choice of indicative-declarative mood systems in the speech function statement but with certain conditions. The condition is that not all Sulțan questions are answered in accordance with Sultan's wishes. Juha presents the opposite. When Sulțan wants a long answer, Juḥa gives an irrational answer. Whereas when Sulțan gives a straightforward question, Juha gives a long and detailed answer. In addition, for the purpose of carrying out commands to the interlocutor, Juha maximizes the variety of mood system choices that exist in the command speech function. Juha places the use of the speech command functions of the indicative-declarative, indicative-interrogative, and imperative mood systems, at the right moment in the conversation.

This diplomacy strategy that is exemplified by Juha can be emulated for anyone who wants to do diplomacy with anyone, especially with parties from higher social classes such as 
between Juha and Sultan. Of course there are a lot of humorous texts and dialogue texts that can be studied more deeply considering the Arab world in its historical record has a lot of humorous figures who are politically literate and are fond of making criticisms both political and social, such as Abunawas.

\section{REFERENCES}

Bahjat, A. (TT). Jucha wa as-Sulthan . Beirut : Darul asy Syuruq.

Bardi, M. A. (2008). "A Systemic Functional Description of The Grammar of Arabic”. Thesis, Ph. D. Sydney: Macquarie University.

Bisri, A. M. ( 2016). Dari Canda Nabi \& Sufi Sampai Kelucuan Kita. Rembang: CV. MataAir Indonesia.

Djatmika. (2012). Perilaku Bahasa Indonesia di Dalam Teks Kontrak, dari Kaca Mata Linguistik Sistemik Fungsional. Surakarta: UNS Press.

Farraj, A. a. (TT). Akhbaaru Jucha. Kairo: Maktabah Mishr .

Gerot, L. d. (1995). Making Sense of Functional Grammar. Sydney: Antipodean Educational Enterprises (AEE). .

Halliday, M. (2014). An Introduction of Functional Grammar. London: Arnold.

Mahsun. (2007). Metode Penelitian Bahasa, Tahapan Strategi, Metode, dan Tekniknya. Jakarta: Rajawali Press.

Mudawwam, S. (2004). “Analisis kesalahan logika pada cerita lucu Nasreddin Hodja dalam buku Nawa>dir Jucha> al Kubra”. Skripsi. Malang: Universitas Negeri Malang.

Najar, M. R. (1978). Juchaa al Arabiy. Kuwait: Aalamul Ma’rifat.

Qani'ah, B. (2016). “Analisis Registers Teks Editorial The Jakarta Post yang Mengulas Capres Joko Widodo dan Prabowo Subianto pada Pemilihan Umum RI 2014 (Pendekatan Systemic Functional Linguistics)”. Tesis. Surakarta: Universitas Sebelas Maret.

Santoso, R. (2003). Semiotika Sosial: Pandangan terhadap Bahasa. Surabaya: Pustaka Eureka.

Sudaryanto. (1986). Metode Linguistik: Ke Arah Memahami Metode Linguistik. Yogyakarta: GMU Press.

Sudaryanto. (2005). Metode dan Aneka Teknik Analisis Bahasa, Pengantar Penelitian Wahana Kebudayaan secara Linguistik. Yogyakarta: Duta Wacana University Press. 
Sutama, P. (2011). "Sistem MOOD Bahasa Bali”. Linguistika. Vol. 18 No. 35 Universitas Udayana.

Widyasari, M. (2014). “al Fakaahatu fi Nawaadir Jucha”. Skripsi. Yogyakarta: Universitas Islam Negeri Sunan Kalijaga. 